\title{
A Hungarian and a Lebanese Seer ${ }^{1}$
}

\author{
Bea Vidacs \\ "East-West" ERC Research Group, Institute of Ethnology, RCH, \\ Hungarian Academy of Sciences, Budapest
}

\begin{abstract}
The paper compares the visions and activities of a Hungarian and a Lebanese female seer, both of whom relive and re-enact the Passion of Christ on a regular basis. The former performs the Passion on the first Friday of the month and weekly, during Lent, while the latter does so once a year on Good Friday. Based on fieldwork by the author among the followers of the seer in Hungary and the work of Emma Aubin-Boltanski and Nour Farra-Haddad in Beirut, Lebanon, the paper discusses the history and background of the seers, the locations where the apparitions take place, and the followers who gather around them. It describes the performance of the Passion itself, the messages the seers convey to the faithful, and the many ways in which the women's activities and the mis-en-scene of the apparitions connect to the larger world and thus fit into universal patterns of modern, apocalyptic visions. While strengthening the faith of the followers, the devotees also receive reinforcement in questions that seem existential to them existential, in as much as members of both groups see the historical drama of their own nation.
\end{abstract} Keywords: Vision of Christ, the Passion of Christ, Hungary, Lebanon, nationalism

\section{INTRODUCTION: TWO VISIONARY WOMEN}

On April 25, 1993, a 36-year-old Catholic woman, married with two children and living modestly in Southern Hungary, had a vision. Although at first she did not know what was happening to her in the weeks and months that followed, she came to realize that she had seen Jesus Christ, who from then on appeared to her on several occasions, speaking to her and instructing her. The event was greeted with enormous curiosity and a small group formed around her, coming to her abode in the village almost daily to witness the presence of Jesus Christ. During this initial period, the woman also healed through the laying on of hands, and in addition to the core group, a very large number

${ }^{1}$ The research leading to these results has received funding from the European Research Council under the European Union's Seventh Framework Programme (FP7/2007-2013) / ERC grant agreement № 324214 
of curious visitors also came to see her. The gatherings took place in the family home of the woman's husband or, in good weather, in the family's yard. As autumn came, the core group, many members of which still belong to the most trusted circle of the woman, erected a marquee in the yard. This was the first step toward the creation of a holy place, later complemented with a chapel and an open air Way of the Cross. During Lent the following year, at the request of Jesus Christ, she first experienced parts of the Passion of Christ on Fridays, and then on Good Friday, after further entreaty by Christ and lengthy soul searching, she accepted the call to undergo the entire Passion. Ever since this first occasion, she has been reliving the suffering of Christ, "walking the Golgotha"2 again and again every first Friday of the month and every Friday during Lent, at the time of this writing for twenty-three years.

At first, enormous crowds arrived to witness these occasions, even though her fellow villagers never quite accepted her and the Catholic Church has been adamantly opposed to the visions, having regarded the seer with animosity from the very beginning. Over time, the number of pilgrims has decreased, but even today "the Golgotha" takes place in front of 100 to 140 people.

Besides the reliving of the Passion on first Fridays or during Lent, the seer meets twice a week (Tuesdays and Thursdays) with a smaller group of her followers for the purpose of a prayer evening of atonement. In addition, they hold a morning of prayers on the thirteenth day of each month in memory of the appearance of Our Lady of Fátima. On first Fridays and each Friday of Lent, pilgrims arrive from all corners of the country, and to a lesser degree this is also true of the thirteenth of each month.

In Beirut, Lebanon, a Maronite Christian woman, married with three children and living under modest circumstances, has also been undergoing quite similar experiences for more than twenty years. Her activities resemble those of the Hungarian seer in that she also relives the suffering of Christ, albeit only once a year, on Good Friday. Unlike the Hungarian seer, at this time she also develops stigmata. In addition, every Tuesday morning she has visions, when primarily the Virgin Mary or a locally important saint, for example Saint Rafqa ${ }^{3}$ or St. Charbel", "seize" or "overtake" her (AuBINBOLTANSKI 2014:519).

Both are marginalized women of little education to whom their surroundings did not attribute much importance before they had begun to have visions. Their modesty, simplicity and ignorance, as in the case of many other seers, contributes greatly to their credibility in the eyes of their followers because it proves that they owe their knowledge to their direct links with the divine. One of their most important traits is that they are both completely ordinary, yet extraordinary.

In addition to both women being considered "holy" people, their comparison is warranted by the fact that they both claim to relive the Passion, which can be classified as instances of Imitatio Christi. Although the comparison of these two particular women may seem arbitrary, I believe that the enormous geographical distance between them may help shed light upon the most important characteristics of this type of seer.

\footnotetext{
${ }^{2}$ This is how members of the community collectively refer to the seer's reliving of the Passion

${ }^{3}$ Saint Rafqa (1832-1914), Lebanese Maronite nun, canonized by Pope John Paul II in 2001.

${ }^{4}$ Saint Charbel (1828-1898) Lebanese Maronite monk, canonized in 1977.
} 


\section{SOURCES}

The material concerning the Hungarian seer comes from my own anthropological fieldwork, based primarily on participant observation and supplemented with information from the publications of her pronouncements by the group surrounding her as well as the not too numerous, mostly religious publications about her.

I only know the activities of the Lebanese woman from secondary sources, contextualized in different ways. Two researchers have written about her. One of them is Nour Farra-Haddad, who teaches at St. Joseph University in Beirut, the other being Emma Aubin-Boltanski, who is a researcher of the National Centre for Scientific Research (CNRS) in France. In addition to reading their articles, written both separately and in collaboration with each other (AUBIN-BOLTANSKI 2013, 2014; AUBIN-BOLTANSKI FARRA-HADDAD 2014; FARRA-HADDAD 2013), I have also closely studied a documentary prepared by Aubin-Boltanski and thus have a relatively thorough impression of Catherine's ecstasy. There is considerable overlap between the publications in terms of ethnographic detail: the analysis is based on the same empirical material (the 2011 Passion enactment by Catherine), although the articles approach the phenomenon from differing points of view. The descriptions consist in part of the sociological characterization of Catherine, a brief discussion of the composition of her visitors as well as of her relationship to the Maronite Church. In part, the authors also acquaint the reader with the family, surroundings, social position and the apartment of the seer, all the more so as the latter, as the backdrop of the visions, is important for understanding the phenomenon. In addition, the authors analyse in detail the most important vision, that of Good Friday, when Catherine experiences the Passion. As core information, these themes appear to a greater or lesser degree in all of the publications, and besides providing analyses from various points of view, the individual articles do not contain much additional information, or rather they help give a more nuanced understanding of the same set of data. This may sound like criticism, but it is not intended as such. I merely wish to point out that despite there being four publications about Catherine (totalling 66 pages), my empirical knowledge of her is in fact rather limited. The documentary film helped a great deal in visualizing and understanding what one reads about. However, it seems that much of it is the video recording of the same vision (Good Friday 2011) which Aubin-Boltanski's analyses in two of her writings (AUBIN-BOLTANSKI 2013, 2014).

Besides introducing the phenomenon, the studies partly concentrate on how Catherine becomes credible (for example, how her ordinariness and extraordinariness complement each other, or how uncertainty and indeterminacy contribute to her credibility as a seer. ${ }^{5}$ Besides these factors, the authors discuss aspects of Catherine's visions that need explanation because they do not fit into our expectations: for example, the way in which Catherine is touched by her followers during her ecstasy would be unacceptable outside it, (the phenomenon is explained with the concept of iconicity), or the seeming contradiction to the teachings of the Church when Catherine seems to merge the sufferings of Jesus Christ and the Virgin Mary in the course of her vision.

\footnotetext{
${ }^{5}$ The majority of these traits are remarkably similar to those appearing in the Hungarian case.
} 
Initially, I conducted interviews among the followers of the Hungarian seer. However, due to external constraints, this form of data gathering had to end fairly soon. As the authors dealing with the Lebanese seer do not cite from interview materials (the documentary constitutes something of an exception to this, partly containing interviews with some of the participants while certain individual reactions are simply there to be seen), wherever possible, I too will refrain from citing from my interviews for greater comparability.

\section{SEERS}

In a 1973 article, William Christian differentiates between seers of local and universal significance (Christian 1973). It seems clear that the content as well as the "target audience" of the visions can vary depending on place and time, and can adapt to expectations and circumstances, but it is impossible to make a one-on-one correspondence between eras and types of seers.

The visions of modern seers often take place publicly, at a predetermined point in time, and usually they see the Virgin Mary, who conveys a message that is not merely of local significance but addresses the whole of humanity. The two seers discussed in this paper happen to undergo the sufferings of Jesus Christ, but the visions also take place in public and at a point in time known in advance. Precisely because of these characteristics, Christian refers to this kind of vision as public visions (cf. ZIMDARs-SwARTZ 1991). Since the middle of the nineteenth century, the number of these has multiplied. The visions held to be the most important in our day and the shrines that came into being in their wake belong to this category: La Salette (1846), Lourdes (1858), Fátima (1917), Garabandal (1961), San Damiano and of course Medjugorje (1981).

The shrine of Szőkefalva in Transylvania (Seuca, Romania) (GYőRFY 2012; PeTI 2012; Pócs 2008, 2010) can also be regarded as such, but the Bulgarian visions studied by Galia Valtchinova also belong here (VALTCHINOva 2009) just as do the visions of the women examined here. In these cases, the messages primarily have national relevance, or at the least they reach the universal through the national. It may also simply be the case that the objectives of the messages are universal but that the conditions under which the seers perform their activities are such that they do not become well-known to a wider audience and therefore cannot be really considered universal. Christian also recognizes this possibility when he writes that shrines of which the Church does not approve eventually cease to exist, or that their activities and influence are much reduced and felt to a lesser degree (Christian 1973:109). At the same time, it is characteristic of accepted shrines that the Church "co-opts the movement" (CHRISTIAN 1973:108) and that the seer is bypassed as a potentially detrimental factor in the development of the shrine as the Church is far more capable of making the cult universal without the seer. For this very reason, the death of the seer is frequently not an impediment to the functioning of the shrine. 


\section{THE TWO LOCATIONS}

The two sites provide a backdrop for the activities of the seers and contribute greatly to the effect they have, but also influence how they function as well as the opportunities open to them. The Hungarian seer lives in a village of about 4000 inhabitants, 18 kilometres from a small town. Prior to the time she began to have visions, she had lived with her husband and her two young children at her in-laws'. She herself was born in a nearby village in a rather poor family with many children. She abandoned her studies after primary school at the age of fourteen and began working in a factory at an early age. She was a sickly young woman, who had undergone several operations. Following her first vision, she was "cured" of her ailments, but even currently she is on a disability pension. In the eyes of her followers, her unimportance prior to becoming a seer serves as significant proof of the divine origin of her transformation.

When the woman began to have the visions, a large number of visitors began to flock to her. The local priest was so opposed to her that at one point he banned the group from attending mass. Under these circumstances, Jesus Christ suggested to her that they should build a chapel in her husband's family yard with the active participation of the members of the group and the financial support of her followers, some from as far away as Australia. They also constructed living quarters for her and her family at the same time. In the course of just a few years, the group created a "multi-functional" sacred place: three spaces that are considered to be sacred; a marquee, where the vision of the Stations of the Cross and the enactment of the Passion of Christ takes place; a chapel, where pilgrims gather, mass is held, and where the faithful can listen to the messages of Jesus Christ after the Passion is over; and an open-air Stations of the Cross with a Crucifix at the far end. Among these, the marquee was the first to be erected. Although the chapel began functioning in 2000, the marquee retained its sacred status, as Jesus Christ had announced that it was a holy place that must not be dismantled. The visions take place here. The walls of the marquee are laden with a variety of images considered to be holy: primarily representations of Jesus Christ and the Virgin Mary, roughly of equal measure. In addition, we can also see a series of smaller prints showing the Stations of the Cross. These are partly placed between the larger images and some are hung on the wooden poles holding up the marquee. There are also images of Pope John-Paul II, the Cardinal Mindszenty ${ }^{6}$ and an image of the Shroud of Turin. The layout of the chapel was inspired by Jesus Christ. Unlike the marquee, its furnishing is completely undecorated, lending the building an almost puritanical air.

Catherine, the Lebanese seer, lives in a rather poor neighbourhood in a suburb of the city of Beirut, with her husband and two children. Her oldest child, now married, had also lived with them earlier. She receives the faithful in her three-room rented apartment, where her living room serves as the venue of her visions while she uses the family

\footnotetext{
${ }^{6}$ Cardinal József Mindszenty (1892-1975); imprisoned for his views by both the Hungarian Arrowcross Party during World War II and the communist regime in 1949, Mindszenty became a symbol of resistance to both fascism and communism. After 1956 he was granted asylum by the United States and lived on the premises of the US Embassy in Budapest until 1971, when he was allowed to leave Hungary. He died in Vienna four years later.
} 
sleeping quarters for occasional consultations. Roughly fifty people can fit into the living room where the visions take place, so many members of the crowd gathering for the visions are obliged to stand on the landing of the building. For this reason, it is a special task for someone to repeat Catherine's words into a microphone during her visions so that those standing at the back or outside can also hear them. At the same time, there is also a "secretary", who writes down by hand all of Catherine's manifestations, including not only her words, but also the meta-communicational elements (she smiles, she suffers, etc.) (FARRA-HADDAD 2013:49).

Similarly to the marquee of the Hungarian seer, Catherine's living room is decked with holy images and statues and here too there appear some saints of local significance: especially St. Charbel and St. Rafqa, who are represented in the room in both picture and statue form. These images have further significance in the Lebanese case as they "ooze" oil that is held to have curative powers and as such contribute to the holiness of the place; cotton wool saturated with this oil is carried far afield by the faithful. In the documentary, we can also see that the priest who is present draws a small cross on the forehead of the faithful with the liquid seeping from the statue of St. Charbel. The fact that this substance is in continuous supply is a contributing factor to Catherine's fame and serves as proof of her holiness.

Neither woman refers to herself as a Saint or holy, nor as a visionary or seer. In the following, I will refer to the Hungarian seer as Erzsike (a pseudonym, diminutive of Erzsébet i.e. Elizabeth). Usually she is referred to as Erzsike, especially, it would seem, when she is spoken of in her capacity as a seer. When talking about the ordinary woman, people tend to use the more prosaic Erzsi - most often within the family. Jesus Christ originally called her "my chosen servant Erzsébet", but lately He has been using the term "chosen Erzsébet" or "my chosen sibling Erzsébet", at times referring to her simply as Erzsébet.

The publications discussing Catherine use the word visionary (visionnaire) as an etic category and tell us that her followers refer to Catherine as "little saint", or "mother of all". As Aubin-Boltanski and Farra-Haddad point out, if seers were to refer to themselves as visionaries or prophets, it would be unseemly as this would not convey enough humility (AUBIN-BOLTANSKI 2014:513). The term "holy" is not used in connection with the Hungarian seer either, the closest designation being when she is referred to as the "chosen one," but this occurs very rarely.

\section{THE FOLLOWERS}

With regard to their social background and place of origin, the followers of the Hungarian seer are rather mixed. Perhaps it is worth differentiating between the "locals", who are either from the nearby town, neighbouring villages or the village of the seer herself, and pilgrims who come to see the apparition from further away. Part of the former constitute the small core of people who are responsible for overseeing the smooth functioning of the apparition event. Those who participate in the prayer evenings once or even twice a week with more or less regularity in addition to the monthly apparitions and Fátima prayer meetings constitute a somewhat larger group. The pilgrims come from all corners of Hungary and there are some who regularly arrive to see the apparitions from beyond the borders of the country. 
The participants at the apparitions are primarily women, just as at all other events that take place around the seer. There are peasant women from rural areas among them, but there are also urbanites as well as those who perhaps live in villages or were at least born in villages but became factory workers, in addition to those who work or have worked as office workers or in the service sector (trade, health services, entrepreneurs, transportation, etc.).

Although I had no opportunity to collect systematic information regarding either occupation or education history, I think it likely that a relatively large number of them have had a secondary education, and there are even university graduates and $\mathrm{PhD}$ holders among the regular attendees. With regard to age, the composition of the followers of the seer is much more uniform. The overwhelming majority of the faithful are above 65 years of age - there are very few young people among them. Based on personal conversations, interviews and the witnessing that takes place (at the behest of Jesus Christ) after the apparitions on first Fridays, I have the impression that the number of widowed (especially, widowed young) and divorced women among the pilgrims is relatively high, which is only to be expected.

In the aforementioned article, William Christian describes the visitors of international, public apparitions, thus: "The typical follower of these cults on the international level is a quiet, anguished person, often with a personal life marked by tragedy, who is struggling to know God. The apparitions for them provide information on divine will, confirmation of divine justice, and reassurances of divine love" (Christian 1973:112). The second part of the statement can be applied to the majority of the pilgrims visiting the Hungarian seer without misgivings. However, the first sentence of the quotation does not quite fit the case. Although I have the impression that many have been afflicted by some tragedy and that some are seeking to "know God", there are a considerable number of people among the followers of the seer who, both for the external viewer and according to their own reckoning, are at peace and happy precisely because of their connection with the seer.

In my view, the difference may stem from the fact that the international pilgrims characterized by Christian do not visit the same shrine with monthly regularity as do the followers of the Hungarian seer. At the same time, these repeat visits create a community around the seer, which brings friendship and solidarity to the pilgrims and strengthens their sense of belonging. Naturally, there are also those among the pilgrims who are "seeking", and Christian's characterization fits them much more precisely (cf. SUTCLIFFE 2000). In any case, as we shall soon see, many of them frequent several pilgrimage sites.

The majority of the few men who attend are married; often they come to the apparitions, and somewhat less regularly to some of the other events, together with their wives. Men hold a disproportionately large number of organizational roles. This is partly due to the fact that one of the possible and very important "offices", the role of "bastion", can only be fulfilled by men. Their task is to protect the seer in general and, at the end of the Passion, to carry the "dead" Jesus Christ out from the marquee in a blanket, as well as some other tasks, such as the handling of the technical equipment.

Many have attended the Hungarian seer's apparitions faithfully since the very beginning, and even among those who came at a later point, there are many who are present at the enactment of the Passion month after month. Some of them are also present at the prayer meetings in remembrance of the Virgin of Fátima on the thirteenth, while some pilgrims only come to one or the other. Arriving at the seer's village on first Fridays 
is made somewhat easier by the fact that a specially chartered "pilgrim bus" is run from the capital to the pilgrimage site every time there is an apparition.

The faithful also visit other holy places. Many have been to the major international pilgrimage sites: primarily Medjugorje, but also Mariazell, Lourdes, Garabandal and Fátima, but many have also had the opportunity to visit the Holy Land. Such trips have been organized by the members of the group together, but some have gone on their own initiative, either on their own or with other organized groups. In addition to these international pilgrimage sites, many visit pilgrimage sites individually or in organized groups in areas inhabited by Hungarians, both within and outside the borders of Hungary. For example, many have been to Kadarkút or Fallóskút in Hungary, but also to Nagyfalu (Nuşfalău) and Szőkefalva (Seuca), both Hungarian-speaking villages in Romania, and many among them participate in the Csíksomlyó (Șumuleu Ciuc, Romania) pilgrimage at Whitsun from time to time. At other times, those who are regulars at the apparitions travel to various prayer meetings for atonement and to other spiritual practices organized in different parts of Hungary, and most of them play an active role in their local Catholic parish.

Jesus Christ often emphasizes in His messages that one must also visit "my Father's house", meaning that it is not enough merely to attend the apparitions - people should also regularly go to church. This exhortation also tells us something about the group's relationship with the Catholic Church. Both the seer and her followers profess themselves to be Catholics. However, the Church does not accept the apparitions as credible. Over the course of years, no genuine investigation by the church has ever taken place, but the Archbishop of the diocese, who would be entitled to carry out such an investigation, from time to time issues an edict forbidding both priests and the Catholic laity from participating in the apparitions, or from partaking in masses in the chapel maintained by the group. The followers of the seer see this as unjust. It pains them greatly, and they often mention bitterly that the Archbishop has never taken the trouble to visit and see for himself what was going on in their midst. These sentiments are partly dictated by a fervent desire to be accepted by the Church and partly by a genuine feeling of being an integral part of the Catholic Church. They may also explain why the group observes liturgical rules so strictly and follows the general prescriptions of the Church (for example, the decoration of the altar) very carefully.

Despite the injunctions of the Church, there has always been a priest, usually not under the jurisdiction of the Hungarian church, who has accepted the role of spiritual advisor. Most recently, an elderly priest who had spent his active life in Germany was the spiritual leader of the community for fourteen years, and ever since his death in September 2015 the entire congregation has been praying and hoping for a successor.

Erzsike's immediate surroundings, the village where she lives and the surrounding settlements have never accepted the apparitions as genuine. Especially at the beginning, many were extremely antagonistic towards her and her entire family. This attitude was also exacerbated by the pronounced enmity of the local priest at the time, although currently she regularly attends local church services and had her grandchildren baptized there.

The composition of the followers of the Lebanese seer is even more varied than that of the Hungarian seer. Based on both the descriptions and the film, although women clearly constitute the majority of the congregants, there are many more men present than in the Hungarian case, at least on the occasion of the Crucifixion that takes place 
once a year. The large number of young people is very noticeable, and even children are present on these occasions. Aubin-Boltanski and Farra-Haddad both stress how varied the composition of Catherine's circle of followers is with regard to both socio-economic position and religious belonging (AUBIN-BOLTANSKI 2014:519; FARRA-HADDAD 2013:51). There are even occasions when, in this religiously divided country, Muslims visit the Maronite Christian Catherine.

Unlike her Hungarian counterpart, the Lebanese seer is not as unique a phenomenon as Erzsike is. Both authors writing about her frequently indicate that there are several more or less similar seers (mostly women, but also men) who have similar apparitions and constitute a kind of network in Lebanon (AUBIN-BOLTANSKI 2014:512; FARRAHADDAD 2013:44). However, the publications I have read from the two authors only discuss Catherine in detail and only mention the others in their introductions.

According to Aubin-Boltanski and Fara-Haddad, there are those among the followers who visit several seers in the "network" while others only follow a single person. Among the seers, some receive both Christians and Muslims and are in favour of understanding and peaceful relations, while others only receive Christians and seem less open to other religions.

Catherine is a member of the Syriac Maronite Catholic Church. As mentioned above, she is among those seers who receive both the Catholic and Muslim faithful. The Maronite Church - although it views Catherine and the other seers with suspicion - has appointed a spiritual leader to each of the seers (AUBIN-BOLTANSKI 2014:514) who, at least in the case of Catherine, does not interfere with what takes place but rather acts as an observer. Despite this, Catherine and her helpers, just like the Hungarian seer and her followers, stick to the rules of the Church carefully and make sure that Catherine does not appear in the media. This is also true of the Hungarian seer. Although she was open to giving interviews to the media at the beginning, with time she has stopped doing so. Catherine is regularly visited by members of the Maronite church from all ranks, and they participate as spectators in the apparitions, though not in an official capacity. Similarly to the Hungarian seer, the pronouncements of the Lebanese seer emphasize and support the importance of the Church (AUBIN-BOLTANSKI - FARRA-HADDAD 2014:87).

\section{THE PASSION}

Both women are famous for undergoing the suffering of Jesus Christ, the Passion. In the case of the Hungarian seer, Erzsike, this happens on the first Friday of every month, and during Lent every Friday. Catherine, the Lebanese seer, only experiences the suffering of Christ once a year, on Good Friday, but every week she sees the "saints" and the "Virgin Mary", who, according to the authors, "invade" her. At times they even speak of possession.

Erzsike fasts on the day of the Apparition, receiving pilgrims until the beginning of the six o'clock mass, when she briefly addresses those gathered together. After the mass, she speaks at greater length to the faithful. This is followed by her going around the chapel to present all newcomers with a special five-colour rosary. As she does this, she may exchange a few words with some, extend a hand to others, while some of those present may reach out and touch her or stroke her gently. Not long after this, following an invocation, when she starts out from the chapel towards the marquee, singing, some 
are already seated in the marquee while others remain in the chapel because this is where they want to watch the apparition broadcast live on a screen. Others will stand guard with lit candles placed inside cut-off plastic water-bottles on either side of Erzsike's route to the marquee.

From the very start, the group has recorded on video all the manifestations of the divine presence as they come through Erzsike. This includes all the masses as well as both the apparitions and teachings of Jesus Christ. These are not made public, but while the apparition lasts, what happens in the marquee is broadcast inside the chapel on a screen. Thus, even those who cannot fit into the marquee, or who simply do not want to watch the Golgotha at close hand, can see the apparitions.

The apparition has a precise structure, in which everyone knows his or her part. On the one hand, the seer always sees more or less the same events: she witnesses the last days of the life of Jesus Christ, suffering through the Stations of the Cross and the Crucifixion. On the other hand, those helpers nearest to Erzsike know the precise sequence of events. Erzsike's sister sits at the far end of the area where the Passion takes place, farthest from the altar, and makes sure that Erzsike does not step out of this area, especially towards the end of the event. During the apparition, when she is gagging from the pain, her husband wipes her mouth, or wipes away the spittle dripping from her mouth, which might fall on the carpet. It is also her husband who brings in the blanket, always the same one, in which the "bastions" carry out the "lifeless" body of Jesus Christ, first carrying it around in the chapel and then into her own house, which is in the immediate vicinity of the chapel.

In the course of the apparition, Erzsike sees and hears Jesus and His disciples. She accompanies them to Bethany and witnesses the raising of Lazarus from the dead, enters Jerusalem with them on Palm Sunday, and is present at the Last Supper and when Jesus washes the feet of the disciples as well as at the Garden of Gethsemane. She is there when Jesus is captured, sees Him being questioned and humiliated in front of Pilate. She then walks along with Him to Mount Calvary and is an eyewitness to the Crucifixion.

She speaks about Jesus Christ and what she sees in the third person singular, as a witness. Nonetheless, she visibly experiences His bodily suffering on her own body, that is to say, as Jesus. (She shudders, her body shrinks back when scourged, and at times she will scream. She is in pain when the crown of thorns is placed on Jesus's head, and when Jesus falls along the Stations of the Cross, she can barely stand up.) Despite this bodily identification with Christ, she uses the third person singular throughout her commentary. Thus, the textual and bodily manifestations of the seer are separated from each other. What she says (the text) describes the events from the outside, while her physical reactions and her body language indicate that she lives through the events bodily (internally?). This duality indicates a constant back and forth, a continuous switching of the point of view, at the same time requiring the spectator to do the same.

Following the crucifixion Erzsike speaks in the first person singular for the first time, addressing those present as "I, your Lord Jesus Christ". As Jesus, she appoints two or three people who are to give testimony in the chapel and then the four above mentioned "bastions" carry her out of the marquee in a blanket. They first take her to the chapel and then into her own house, from where - after the testimonies of the persons just appointed through her - she conveys the teachings of Jesus Christ as the congregation watches and listens in the chapel. Erzsike also speaks in the first person singular as Jesus Christ during 
the teachings. These may last about twenty-thirty minutes and focus on various tropics. (These include detailed reflections on certain parables or other themes relating to faith, such as the importance of prayer or how to pray correctly. Another important strand in the messages contains advice concerning the conduct of life, as for example the importance of self-knowledge or the necessity of having goals in life.) These teachings have been recorded (with sound and vision) since the beginning, and the texts are published in a monthly pamphlet and sold very inexpensively. (It is also available free of charge on the internet, but many of Erzsike's followers do not necessarily have access to the internet or feel more comfortable with the printed text.)

Erzsike does not refer to what happens to her as seizure or being invaded. She could in fact call it that since she finds herself in the Holy Land and sees what happens there in person. Her followers hold that during the time of the enactment of the Passion she herself does not feel bodily pain; it is as if she was there "in spirit". The bodily suffering that the spectators see is the suffering of Jesus Christ and not that of the seer's person. Following the Crucifixion, however, when she starts talking in the first person singular, they consider that Jesus Christ has appeared among them in person and is speaking through Erzsike (borrowing her voice as it were).

On the one hand, the presence of the spectators helps Erzsike live through the Passion experience and helps her fulfil her mission, while on the other hand, by empathizing with her, to some degree they also take part, identifying with Erzsike and through her with Jesus, becoming like Him. As such, with their presence and identification, they too atone and participate in redeeming humanity. Becoming similar to Christ (that is to say Imitatio Christi) is holiness itself, the highest degree of identification with the divine, which at the same time, significantly, also renders their faith deeper. The enactment of the Passion can also be regarded as a co-production in another sense: the active interpretation of those present is needed for it to "work". The spectators are not merely spectators: through their empathy they accompany Jesus along the Stations of the Cross. Several people identify bodily with the seer, kinetically experiencing what she is experiencing. Some recount that they hear certain sounds during the apparition: for example, during the crucifixion they hear the sound of the hammer, even in the neighbouring chapel, while others claim to feel physical pain when Christ is being beaten, and others simply try to mentally follow in Jesus's footsteps along the Stations of the Cross.

As I mentioned before, the analyses concerning the Lebanese seer primarily deal with the Good Friday apparition that occurs once a year and do not go into detail on what happens on those occasions when Catherine does not experience the passion, but is "seized" by various saints, or when the Virgin Mary or Padre Pio appears to her.

According to Aubin-Boltanski and Fara-Haddad, Catherine also sees and feels not only the Crucifixion itself but also the Stations of the Cross. However, their accounts almost completely skip the latter and pay far more attention to what happens on the Cross (Aubin-Boltanski 2014). When Catherine appears in the crowded living room, she first kneels and prays; then she falls over and lies suffering on the floor. Her stigmata begin to show: the cross on her forehead, the traces of "nails" in her palms and on both feet, as well as traces of the spear on her side. The cross that appears on her forehead is a reinterpretation of the stigmata of Christ, since if anything there should be traces of the crown of thorns there (these, however, are not considered by the Catholic Church to be part of the stigmata in any case). Even more unusual is the "Lebanon" inscription that 
appears on her chest. I will return to the relationship of the seer to Lebanese national identity, but it is quite clear that the issue of Lebanese national unity forms an important aspect of the vision in a country which is divided both in religious and political terms and in which the memories of the civil war (1975-1990) are still alive.

Catherine does not lie long on the floor. As soon as she begins to suffer visibly on the cross four men lift her and place her on a sofa. For the remainder of the apparition, she remains there, covered with a decorated child's sheet - she partly suffers the pain of crucifixion, and partly conveys messages. Her undergoing of the Passion is much more static than that of Erzsike: she lies in a rigid posture for several hours on the sofa and in effect experiences death by crucifixion. The film shows how she suffers, moans in pain, sheds tears and protests, at times as Jesus Christ and at times as the Virgin Mary. (On the one hand, we can hear Jesus's words on the cross from her mouth "Eli Eli lama sabachthani?" (Matthew 27:46 \& Mark 15:34, My God, My God, why have you forsaken me?), while on the other she also exclaims as the Virgin Mary: "No! My Son! My Son! No!"). That is to say, Catherine feels the pain of Jesus Christ and the Virgin Mary all at the same time, so much so that one of the participants raises the question of who exactly died on the cross. It is especially interesting that the question comes from the mouth of the "secretary", that is to say someone who is an important member of the core group surrounding Catherine (AUBIN-BoLTANSKI 2014:516).

While she is lying on the sofa, suffering on the cross, some of her followers queue up one by one to speak to her: they whisper into her ear and at times she also says something to them in a low voice. Finally, they kiss the cross that is in her fist. The "volunteers" oversee who will be the one to enter into direct contact with the seer. At times, Catherine herself will ask for someone. The "secretary" sits next to her and writes down everything Catherine says. Later, she makes a clean copy of everything. When a particular individual is concerned, the secretary shares this copy with the person in question; at least this is what transpires from the words of a young woman interviewed in the documentary film.

As can be seen from the above description, unlike the followers of the Hungarian seer, the Lebanese faithful can establish direct physical contact with Catherine, although Aubin-Boltanski (AUBIN-BOLTANSKI 2013:372) specifically refers to an incident when a woman begins to bestow kisses on the foot of Catherine while the latter is in an ecstatic state as a "disturbance", and also recounts that she is stopped by the others present. At the same time, she also mentions yet another person, this time a man, who strokes Catherine's foot while she is having the apparition, and nobody stops him (which can also be seen in the film). According to Aubin-Boltanski, this is a case of iconicity, that is to say, at such times Catherine is treated as an icon, in which case both kissing and stroking are in order.

Although the apparitions follow a schema in both cases, that of the Lebanese seer seems much more immediate than that of her Hungarian counterpart. This might in part be due to the differences between the two venues. Due to the size and layout of Catherine's apartment, her followers can get quite close to Catherine physically, whereas in the case of Erzsike there is more of a distance between the seer and her followers during the apparition. It seems from conversations I have had with Erzsike's followers that earlier they too had a more intimate connection with Erzsike during the apparitions, so it is not impossible that beyond the local circumstances in the case of the Hungarian seer we can speak of a more advanced state of the routinization process, which reduces the number of occasions when there is easy access to the seer. 
Similarly to the Lebanese seer, her Hungarian counterpart also receives the faithful for consultation, especially before the apparition, but also possibly right after the atonement of the thirteenth, yet others will visit her on another day. She is also called on the phone for advice and prayer, and she incorporates these requests into the long invocation preceding the apparition.

\section{MESSAGES}

One of the characteristic features of modern apparitions is the public nature and importance of messages. The prototype of these apparitions was La Salette (1846), but the messages "transmitted" by visionaries were also of great significance in the case of Fátima and several other public apparitions and shrines (cf. TURNER - TURNER 1978; ZIMDARS-SwARTZ 1991). They mostly call for devotions for the Salvation of humankind. Due to their thematic content, discussed earlier, the messages of the Hungarian seer and the "teachings" she conveys from Jesus Christ do not really fit into this picture. However, in other contexts, she often does makes declarations that fit the stereotype, which is to say that she also calls upon people to practice atonement, to pray and recite the rosary regularly.

During Lent, the messages this time, the messages take place weekly, and after Easter they are published as a separate volume as they usually constitute an interconnected whole. In addition, there is a celebration every year to commemorate the first ever vision of the seer, called the Anniversary. On these occasions, Jesus Christ spends several hours among the followers of the seer and leads the group through its own history, recalling important events and calling upon the audience to speak about their memories. What is heard on these occasions is also published as a separated publication every year and recently it has become possible to download it from the internet.

The messages of Catherine, the Lebanese seer, comply much more closely with the expectations surrounding such messages: they call upon the faithful to repent and to atone. They are rather short and generic: "Pray my Children! Confess! Recite the rosary!" (AUbin-Boltanski 2013:380). For this reason, they have no direct connection with the Passion, but due to their content as well as the fact that they are from the lips of a holy person, they fit the general mould of messages inspired by earlier Marian apparitions. As we have seen, at the same time, Catherine also conveys private messages, even on the occasion of the Crucifixion on Good Friday.

\section{THE SEERS AND THE WORLD}

To return to William Christian's article on holy people, according to him perhaps the greatest difference between "folk" and modern apparitions and the holy people associated with them lies in their scale and whether they are public or not. These factors are important precisely because by intention the messages of modern apparitions are not meant for a local audience but rather for a universal one. The messages address all of humanity, not merely a local community. In effect, Christian is talking about a change of scale that comes with modernity. This not only means that the shrine is visited by people 
from afar, as in the case of the most important international pilgrimage sites, but also that the seers, just like their followers, are thinking on a larger than local scale.

From this point of view, it is worth noting that both seers enter into contact with the (primarily Catholic) world beyond their immediate circles and through several channels. This can be seen both in their material world and in their thinking. Holy images, representations of Jesus and the Virgin Mary, are a part of universal Catholic culture. It is typical that a replica of the Lourdes grotto is to be found at both the seers' locations. In the case of Erzsike, it is found outdoors in the yard, wedged as it were between the chapel and the Stations of the Cross. In Catherine's case, there is much less space available. However, amidst the holy images and statues in the heavily decorated "salon" of her three-room apartment, a miniature copy of the Lourdes grotto can also be seen.

At the end of each mass, Erzsike distributes a rosary to those newcomers who desire to receive one. This is a five-colour (plastic) rosary, each decade being a different colour (yellow, white, blue, red, green). As Erzsike explains, she is not asking money for it, but rather that the person accepting it should become "a sibling in atonement" and pray at least one decade of the rosary daily. The colours have a dual symbolism: partly they represent various virtues and features that are significant components of faith (for example faith, fidelity, love, the sacraments), yet the other reading is just as important: the colours represent the five continents, thus the reciting of the rosary in and of itself means that one is praying for the entire world.

The Hungarian seer is also connected to the larger world through the Virgin of Fátima: the monthly prayer meetings serve as occasions for atonement and as commemoration of the apparitions of the Virgin. Another reminder is a statue of the Virgin of Fátima on the altar of the chapel that Erzsike herself chose under divine guidance when she made a pilgrimage to Fátima together with some of her followers. The series of rites that take place in connection with Fátima on the thirteenth day of every month strengthens the group's sense of community while simultaneously reinforcing their sense of belonging to the universal Catholic Church, which they steadfastly maintain despite being rejected by it.

Another important characteristic of modern (and primarily Marian) apparitions is their apocalyptic nature. Their main message is that the world is so full of evil and human sin that atonement is needed in order for humanity to escape God's rightful wrath. This can best be done through prayer, especially reciting the rosary, although the faithful also need to perform the other sacraments (partaking of confession, Holy Communion) and repent. The messages of apparitions suggest that if people pray, more and more souls will be saved and the time spent in purgatory can be shortened. Based on this, Sandra ZimdarsSwartz speaks about an apocalyptic ideology that she characterizes thus: "This ideology is a sort of popular, free-floating apocalyptic worldview, built of images and themes prominent in the messages of the more recent apparitions and can be seen as anchored in almost any one, or any combination of, these apparitions" (ZIMDARS-SwARTZ 1991:247). A fundamental part of this worldview is the idea of "intercession and intervention" (ZIMDARS-SwARTZ 1991:ibid), which in Marian apparitions is usually taken to mean that only the Virgin Mary stands between divine mercy and the wrath of God (or perhaps Jesus Christ). Through atonement, the Virgin Mary can be begged to intervene.

Although the apparitions of Erzsike are not connected to the Virgin Mary at all, her activities are related to atonement in many ways. As mentioned above, the teachings she 
brings do not fit into this mould very well, but many of her other activities and statements do. The motive for undergoing the suffering of Christ already links the apparitions to atonement for the sins of the world. Jesus Christ first asked Erzsike to undertake His Passion because of the sins of priests. Later, He requested that she continue with the sacrifice for the sake of youth. Eventually, her atonement was extended to the whole of humankind, and this continues to be the case to this day. In addition, the presence of the pilgrims at the apparitions and their identification with the seer and with the suffering Christ can also be regarded as atonement. The Fátima commemoration is even more directly linked to the idea of atonement since the Virgin of Fátima explicitly asked the faithful to atone precisely in order to help avoid the apocalyptic end. Therefore, Erzsike's activities can be seen to fit into the universal worldview of modern apparitions, although with regard to their effect the messages (directly or indirectly) conveyed by her cannot be called universal. This is not due to her intentions, but rather to her circumstances. The negative attitude of the Catholic Church has most likely contributed greatly to the fact that the shrine has not become more significant.

\section{THE PASSION AND THE NATION}

Nonetheless, the seer and her group manage to rise above the local context, even if in a slightly different sense. This extends the idea that in this case we can speak of reaching the universal through the particular. Erzsike has stated on countless occasions - as an idea coming from Jesus Christ - that Hungarians have a special vocation in the salvation of humankind. They hold that Hungary will be the originator of the atonement movement that will lead to the redemption of humanity. According to one of her chroniclers, Jesus Christ spoke thus through Erzsike on Good Friday, 14 ${ }^{\text {th }}$ April 1995: "This little country is atoning in the spirit of My own and My Mother's request, with its prayer communities undertaking vigils and fasts so as to redeem the people, humankind, which for the most part is rushing down the slope leading them to damnation" (MolNáR 1995:32). Erzsike was not the first by far to formulate the idea of the special calling of Hungarians; it is rather part of a broader Hungarian "mythology". It was perhaps most prominently expressed by the Catholic nun, Sister Natália, who died in 1992, but also fits well into the goals of the Flame of Love Movement, which also originated in Hungary, and in general into a widely popular set of ideas that have been conceptualizing the country as the "Bulwark of Christendom" (or sometimes of Europe) since the Ottoman occupation in the sixteenth century, and even earlier. ${ }^{7}$

Erzsike returns to the idea from time to time, and not only when Jesus Christ speaks through her but also, for instance, in the course of her divinely inspired addresses to the faithful following the mass. Shifting slightly the context of the idea of a calling, she often brings up the point that although at present many are ashamed of being Hungarian, once they fulfil their calling they will be proud of being so. This chimes rather nicely with the thoughts of Margit Feischmidt on the new national consciousness: "at bottom the 'new national consciousness' appears as a response to structural problems which

\footnotetext{
${ }^{7}$ These are widespread tropes in the region, not limited to Hungary, cf. SRODECKI 2016, but of course they appear to be uniquely true to those who resort to them.
} 
builds on 'national pride' and serves fundamentally to restore collective dignity and selfrespect" (FEISCHMIDT 2014:125). Feischmidt is writing about the worldview of young people in present-day Hungary, but based on the above it seems undeniable that we are dealing with a phenomenon of much broader import. Exactly how broad is also shown by the fact that in Bulgaria we find similar desires (albeit telescoped into the past) for "national grandeur" in the writings of Galia Valtchinova (VALTCHINOvA 2009), for which the "proof" also comes from the apparitions of seers.

As we have seen, Catherine's messages call for prayer and atonement and are quite reminiscent of the messages of the Virgin of Fátima. National consciousness plays an important part in her case too. The publications dealing with her stress that Catherine supports Lebanese national unity and understanding between the various religions. According to Farra-Haddad, Catherine's messages and activity "...preach for a 'living together', apart from socio-political tensions, that is favorable to the construction of a common Lebanese identity" (FARRA-HADDAD 2013:61). As both authors point out, this is a very important aspect of Catherine's activities, which can also be seen from the fact that she became active as a seer at an important juncture in the Lebanese civil war. Lebanon is a multi-confessional country and the mere fact that representatives of almost all religions turn up in Catherine's living room indicates a kind of universality in itself, at least in the Lebanese context. According to Aubin-Boltanski (2014:519), the visitors belong to the following denominations and faiths: Armenian, Greek Orthodox, Syriac, Maronite, Greek Catholic ${ }^{8}$ and Muslim.

The complicated history of Lebanon at the end of the twentieth century has most likely had an effect on Catherine's development as a seer and also on how the faithful present at the Crucifixion interpret what they see. It is in this context that we understand the significance of the fact that the inscription "Lebanon" appears among Catherine's stigmata, which thus becomes a sort of mystically approved stance on behalf of the unity of the country. This seems to be especially important if we take into consideration that the position of the Maronite Church weakened following the civil war. In this light, the appearance of the word Lebanon on the chest of a Maronite holy woman can arguably be seen as validating Maronites in Lebanon.

Aubin-Boltanski calls attention to a different aspect of the question when, in the conclusion to her 2014 article, she analyses the kinds of associations the sight of Catherine experiencing the Passion during Good Friday 2011 may have evoked in the devotees present. According to her, the feelings provoked by the Crucifixion may be regarded as "symptomatic of the distress experienced by Lebanese society" (AUBINBOLTANSKI 2014:519). It should be noted that she made her comments immediately after the outbreak of the Syrian Revolution, which Lebanese had reason to believe would have an effect on their lives as well. Still, I find it even more significant when she adds, "For Catherine's followers, her suffering and stigmatized body mirror the divisions and blows endured by the Lebanese 'homeland', which the Virgin/Catherine designates in her messages as her "second Son"” (AUBIN-BOLTANSKI 2014:ibid).

I think this is where the Hungarian and the Lebanese seer converge the most. Similarly to the Lebanese faithful, the Hungarian devotees also project Jesus' sufferings

\footnotetext{
${ }^{8}$ The Armenians and Syrians can also be divided into further denominations.
} 
onto the trials and tribulations of their country. According to a widespread view among Erzsike's followers, for example, the five parts which had been annexed away from Hungary at the end of the First World War (by the peace treaty of Versailles, which in Hungary is more commonly referred to as Trianon) correspond to the five wounds of Jesus (cf. CHRISTIAN - KRASZNAI 2009; JobBit 2011). It is more than likely that this idea comes from public discourses between the two world wars. After Trianon, Hungarian public opinion often identified the humiliation of the country with the suffering of Christ. There is also an analogy for the second half of the citation: one of the cornerstones of the everyday discourses of Erzsike and the surrounding group is the idea of Regnum Marianum (Kingdom of Mary), which is a given not only for her followers but also for numerous Hungarians (KNAPP - TÜSKÉs 2006; SRODECKI 2016).

\section{CONCLUSION}

I have primarily reviewed the activities of the two seers from the aspect of what is common to them: their undergoing the Passion of Christ. Besides their social parameters (uneducated, marginalized, married women of modest means) the organization and unfolding of the apparitions also have many similarities, although I have not discussed this question systematically (for example, the role of volunteers in the organization of the event, the supportive role of husbands, etc). Although both women live through the same central element of Christian faith, the two events are rather different in their nature. Erzsike's is more dramatic, Catherine's more immediate. Erzsike's spans a longer time period, while Catherine primarily concentrates on the Crucifixion itself. Despite the differences, their devoutness is obvious to their followers in both cases. Echoing William Christian, we can agree that the apparitions strengthen people in their belief. At the same time, however, beyond the mystic experiences, beyond religious belief, the devotees also receive reinforcement in questions that seem existential to them, in as much as members of both groups see the historical drama of their own nation. These views are not unique to the seers and their devotees. Nonetheless, it gives them special credence that they come from Jesus Christ or from the mouths of His chosen servants and in frequent repetition become palpable truth for their followers.

\section{REFERENCES CITED}

\section{Aubin-Boltanski, Emma}

2013 Prêter corps au Christ et à la Vierge crucifié(e)s. Liban 2011. Archivio Italiano della Storia di Pietà XXVI:363-382.

2014 Uncertainty at the Heart of a Ritual in Lebanon 2011. Social Compass 61:511523.

Aubin-Boltanski, Emma - FARra-Haddad, Nour

2014 Présentifier les saints ou l'oscillation au coeur du croire en actes. In AUBINBoltanski, Emma - Lamine, Anne-Sophie - LucA, Nathalie (eds.) Croire en Actes. Distance, intensité ou excès?, 77-87. Paris: L'Harmattan. 
Christian, William A. Jr.

1973 Holy People in Peasant Europe. Comparative Studies in Society and History 15: $106-114$.

FÁBIÁN, Gabriella

2015 The Sacrifice of Atonement in Roman Catholic Communities in the Székelyföld Region. Religion, Culture, Society Yearbook of the MTA-SZTE Research Group for the Study of Religious Culture 2, 58-82.

FARRA-HADDAD, Nour

2013 Staging the Extraordinary Emergence of Divine Entities in the Daily Life of a Visionary House in Beirut. Mediterranean Review 6(1):43-64.

FEISCHMIDT, Margit et al.

2014 Nemzet a mindennapokban. Az újnacionalizmus populáris kultúrája [Nation in the Everyday. The Popular Culture of New Nationalism]. Budapest: L'Harmattan.

GYöRFY, Eszter

2012 Csodák és csodatörténetek a szőkefalvi kegyhelyen [Miracles and Miracle Stories at the Shrine of Seuca]. In Pócs, Éva (ed.) Szent helyek, ünnepek, szent szövegek. Tanulmányok a romániai magyarság vallási életéből, 75-229. Budapest-Pécs, L'Harmatan-PTE Néprajz - Kulturális Antropológia Tanszék. (Studia Ethnologica Hungarica 15).

MolnÁr, Gyula

1995 Magyar Énekek éneke. A sükösdi jelenség [Hungarian Song of Songs. The PETI, Lehel Sükösd Phenomenon]. Nyíregyháza: Nyíregyházi Római Katolikus Plébánia.

2012 Látomások, vallási megtérés és megszállottság. Kommunikáció a transzcendenssel egy erdélyi faluban [Visions, Religious Conversion and Possession. Communication with the Transcendent in a Transylvanian Village]. In Pócs, Éva (ed.) Szent helyek, ünnepek, szent szövegek: Tanulmányok a romániai magyarság vallási életéből, 12-74. Budapest-Pécs: L'HarmattanPTE Néprajz - Kulturális Antropológia Tanszék. (Studia Ethnologica Pócs, Éva Hungarica 15).

2008 Szőkefalva/Seuca: egy új kegyhely üzenetei [Seuca: Messages from a New Shrine]. In Pócs, Éva (ed.) Démonok, látók, szentek: Vallásetnológiaifogalmak tudományközi megközelitésben, 484-504. Budapest: Balassi. (Tanulmányok a transzcendensröl 6).

2010 Seers, Visions and Shrines: Divine Interventions in Crises of Private and Public Affairs. In Valtchinova, Galia (ed.) Religion and Boundaries: Studies from the Balkans, Eastern Europe and Turkey, 195-221. Istanbul: The Isis Press.

SRODECKI, Paul

2016 Antemurale-Based Frontier Identities in East Central Europe and their Ideological Roots in Medieval/Early Modern Alterity and Alienity Discourses. In Antonín Malaníková, Michaela - Antonín, Robert (eds.) Collective Identity in the Context of Medieval Studies, 97-120. Ostrava. 
SuTClifFe, Steven

2000 "Wandering Stars": Seekers and Gurus in the Modern World. In SutcLIFfe, Steven - Bowman, Marion (eds.) Beyond New Age: Exploring Alternative Spirituality, 17-36. Edinburgh: Edinburgh University Press.

TURNER, Victor W. - TURNER, Edith

1978 Image and Pilgrimage in Christian Culture. Anthropological Perspectives. New York: Columbia University Press.

VALTCHINOVA, Galia I.

2009 Re-inventing the Past, Re-enchanting the Future: Visionaries and National Grandeur in Interwar Bulgaria. In Christian, William A. Jr - KLANiCZAY, Gábor (eds.) "The Vision Thing”: Studying Divine Intervention, 157-194. Budapest, Collegium Budapest Institute for Advanced Study.

ZIMDARS-SWARTZ, Sandra

1991 Encountering Mary: From La Salette to Medjugorje. Princeton, NJ: Princeton University Press.

Bea Vidacs is Senior Researcher in the "East-West" Research Group at the Institute of Ethnology of the Hungarian Academy of Sciences. Educated in Hungary and the UK, she obtained her doctoral degree at The Graduate Center of The City University of New York. She also conducted research in Hungary on post-socialist transformations in rural co-operation as part of the Economy and Ritual research group at the Max Planck Institute for Social Anthropology in Halle, Germany. Her book, Visions of a Better World: Football in the Cameroonian Social Imagination (Münster 2010), examines the social and political significance of football. Her publications also include "From PigSticking to Festival: Changes in Pig-Sticking Practices in the Hungarian Countryside", in Stephen Gudeman and Chris Hann (eds.) Economy and Ritual: Studies of Postsocialist Transformations (New York, 2015) and "Blood is Thicker than Water: Transformations in Strategies of Choosing Godparents in a Hungarian Village", Journal of Family History 2018 43(1):12-29. She is currently working on a book-length manuscript on a Hungarian seer and her followers. E-mail: bvidacs@yahoo.com 
